\title{
都市居住地における街区公園・児童遊園の管理方法に関する研究 MAINTENANCE METHODS FOR NEIGHBORHOOD PARKS IN URBAN RESIDENTIAL AREAS
}

\author{
井上 ちUろ*, 藍澤 宏**, 鈴木 麻衣子*** \\ Chihiro INOUE, Hiroshi AIZAWA and Maiko SUZUKI
}

\begin{abstract}
The purpose of this paper is to clarify how to maintain the neighborhood parks continuously to develop, with the viewpoint of the public participation. We examine the government maintenance method, the residents' use and demands, the environmental problems of the parks and the way to solve them.

Main findings are as follows: 1) The each plans for "maintenance of equipments" and "maintenance of environment" are needed. 2) "Maintenance of functions" must be reinforced. 3) The government and citizens should maintain parks taking account of the location, scale, neighborhood management and residents' activities.
\end{abstract}

Keywords : Block-park, Play-lot, Maintenance of parks, Local government, Neighborhood, Public participation 街区公園，览童遊園，公園管理，行政，近隣者，住民参加

1.はじめに

\section{1-1 背景・目的}

都市部の密住化が今なお続く今日、屋外の公園、緑地、広場等の 共用空間は、居住環境の質を高める貴重な要素である。なかでも、 都市公園の内で、誘致圈と規模が最小の街区公園住1)や、各自治体の 条例に基づいて整備される児童遊園注 ${ }^{21}$ は、箇所数や総面積の点で整 備実績が最も多く、近隣住民にとっては“屋外での居場所”として、 また“利用を通じた近隣づきあいを酮成する場”としても期待でき

る、暮らしに身近、かつ重要な空間といえる。

これら街区公園を中心とする小規模な公園は、欧米標準を目賩に 人口あたりの公園面積を増加させるという経緯生3)から、箇所数の增 加が図られてきた。しかし、各自治体による管理の不徹底や利用者 マナ一の悪さから、睘境が悪化している公園も依然としてみられる。 また公園の整備内容が、住民の要望を反映したものではなく、行政 が管理しやすいものになる傾向や、開設後に近隣住民から出る要望 や需要の変化に対応できていないという問題もあり、日常利用の場 としてどのように管理し、さらには質の高い空間へ活用・発展させ ていくかという検討や取り組みは不十分といえる。

公園に関する既往研究は、整備内容や利用実態からみた空間計画 1) 7)を中心に、公園の計画段階を主として考察した研究多899、また管 理方法を主題として既に住民参加の実績のある公園を取り上げた事
例研究 10111 等、数多くの成果が挙げられており、特に近年は住民参 加による公園管理をテーマとした研究への取組みがみられる。しか し、それらの多くは、地域固有の住民活動の発生や経緯を背景とし た個々の実態解明が主となっており、ごく一般的な公園に通ずる管 理方法として適用できるとはいい難い。また、それら住民活動が一 時的な盛り上がりで終息したり、最終的には一部の住民に過度な負 担がかかってしまっているという問題もみられ、住民参加による管 理方法の持続性について未検討な点がある。

本研究では、行政主導で整備され開設から10年以上を経過した街 区公園、及び览童遊園（以下、総称として公園）を対象萑)とし、そ れら“住民の暮らしに身近な公園”という特徴を生かし、“地域の 居場所”となりうる公園を行政・住民協働で作り上げていくことが できる、公園開設後の持続的な管理方法を求めることを目的とする。 1-2 研究方法・調查方法

まず、分析の基本要素として、公園管理に関わる主体と公園管理 の内容を設定した（図 1)。管理主体は、大きく[行政]と[住民]が挙 けられる。ただし、[住民]については、公園を利用・管理しうる住 民として、(1)公園に隣接した家の[近隣者]、(2)それ以外の近隣から の[来訪者]として二区分し、“公園への身近さ”という観点から立場 を考慮した分析を行う。管理内容は、公園環境の維持・向上を図る ために必要なこととして、(1)遊具・ベンチ・水道・便所等の性能や
* 東日本旅客鉄道捧) 修士(工学)

** 東京工業大学教育環境創造研究センタ一 教授・工博

*** 東京工業大学教育環境創造研究センター 助手・博士 (工学)
East Japan Railway Company, M. Eng.

Prof., Research Center for Educational Facilities, Tokyo Institute of Technology, Dr. Eng.

Research Assoc., Research Center for Educational Facilities, Tokyo Institute of Technology, Dr. Eng. 
安全面に倸る 設備管理\}、(2)園路や広場の清掃や植物の手入れ等の 衛生面や快適性に倸る環境管理\}、(3)新しい設備導入や空間活用方 法を検討する $\{$ 機能管理\}の三つを設定住 5)した。

これらの設定を基に研究全体のフローとしては、第一に、行政に よる管理方法の実態、及び行政として取り入れている住民参加型管 理の実態を捉え、行政が設定している管理方法の問題点と課題を明 らかにする。第二に、現在の公園睘境の状況に対する住民の不満・ 要望と、それに対する行政対応、及び住民自身の対応を捉え、公園 管理における主体間の役割関係とその課題を明らかにする。それら を踏まえ、第三に、住民の公園管理に対する参加意向、及び住民参 加型管理の事例を分析することにより、住民参加型管理の在り方を 再検討する。

調査方法は、まず行政による管理内容の比較を行うため世田谷区、 目黒区、大田区の 3 区を取り上げ、各行政に対し管理方法の概要と 課題を捉えるための資料分析、及びヒアリング調査を行った。

また、調査対象の公園として、3区の中から立地や規模·平面構成 による管理方法の相違が捉えられるよう11の公園を選定した(表 1 ， 図 2)。これらは規模、及び避具や広場等の平面構成の相違から、a $\sim d 、 e \sim g 、 h \sim k$ の 3 群に分けられる。a〜dは比較的規模が小さく、 全体に固定遊具が密度濃く配置され、遊具スペースで全体が構成さ れた公園である。e〜gは、a〜dよりも若干規模が大きく、遊具等の 設置物で占められない広場が確保されている。しかし遊具スペース と広場の境界が不明瞭である。 $\mathrm{h} \sim \mathrm{k}$ は、遊具スペースと広場を有し ており、植栽や柵によりそれぞれが明確に分けられている。

これら 11 の公園について、公園環境・住民の利用状況に関する観 察調查、近隣者・来訪者に対する現地でのヒアリング調查、さらに 公園管理に関わっている住民組織に対するヒアリング調查を行った。 主な調査を、実際に公園を利用・管理している住民・組織・行政へ のヒアリング形式とすることにより、具体的な問題点とその要因や 課題を捉え、質的分析を行うこととした。

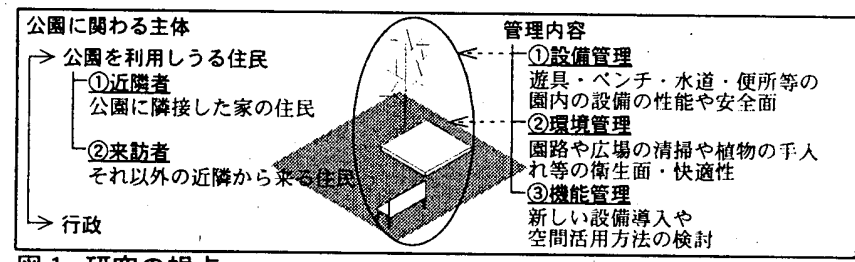

\section{図1 研究の視点}

表 1 調查概要

\begin{tabular}{|c|c|c|c|c|c|c|c|c|c|c|c|c|}
\hline \multicolumn{10}{|c|}{ 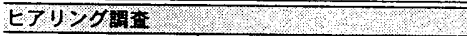 } & \multicolumn{2}{|c|}{ 敌察到查 } & 期間 \\
\hline \multicolumn{5}{|c|}{ 対象 } & \multicolumn{5}{|c|}{ 調查内容 } & \multirow{3}{*}{\multicolumn{2}{|c|}{ 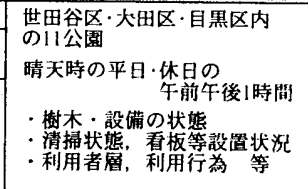 }} & \multirow{3}{*}{$\begin{array}{l}\mathrm{H} \\
14 \\
\mathfrak{9}: \\
10 \\
1 \\
12 \\
\mathrm{H}\end{array}$} \\
\hline \multirow{2}{*}{\multicolumn{5}{|c|}{ 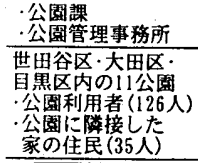 }} & \multicolumn{5}{|c|}{$\begin{array}{l}\text { ・公園事業について } \\
\text { 管理羓務の内言と方法 }\end{array}$} & & & \\
\hline & & & & & \multicolumn{5}{|c|}{ 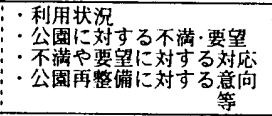 } & & & \\
\hline 鼓 & 性 & 別 & \multicolumn{4}{|c|}{ 年 代 } & \multicolumn{3}{|c|}{ 利 用 頻 } & 度 & \multirow{2}{*}{\multicolumn{2}{|c|}{ 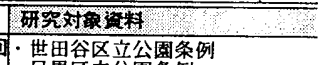 }} \\
\hline & & & $\sim 20$ & & $40-60$ & $70-8$ & ほほ & 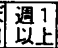 & $\begin{array}{l}\text { 月2.3回 } \\
\text { 以上 }\end{array}$ & $\begin{array}{l}\text { 月1國 } \\
\text { 程度 }\end{array}$ & & \\
\hline & $\begin{array}{lll}\text { a } & 7 \\
\end{array}$ & & & 5 & 2 & 1 & 2 & 3 & & 2 & & \\
\hline & \begin{tabular}{l|l|l}
$b$ & 3 \\
\end{tabular} & & 2 & 3 & & & & 3 & 2 & & & \\
\hline & 5 & & 3 & 2 & & 1 & 1 & 4 & 1 & & & \\
\hline & d 5 & & 1 & & 4 & & 1 & 2 & 1 & & & \\
\hline & e. 6 & & & 5 & 4 & 1 & 1 & 4 & 4 & 1 & 公園一筧表 & \\
\hline & 12 & & 7 & 5 & & 1 & 3 & 8 & & & & \\
\hline & g 13 & & 2 & 12 & & & 4 & 6 & 1 & 3 & & \\
\hline & h 10 & & 1 & 9 & & & & 6 & 2 & 2 & & \\
\hline & i| 16 & & 7 & 8 & 1 & 1 & 8 & 8 & & & & \\
\hline & & \begin{tabular}{|l|}
2 \\
4
\end{tabular} & $\frac{6}{3}$ & $\frac{10}{16}$ & 2 & $\frac{1}{2}$ & $\frac{1}{7}$ & 14 & 2 & 2 & 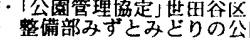 & Pifi \\
\hline
\end{tabular}



図 2 調查対象公園の空間構成 


\section{2. 行政による管理方法の実態}

各行政に対するヒアリング調查、及び資料分析をもとに、行政に よる管理方法の実態と課題を探る。

日常的な管理である\{環境管理\}は、入札単価で業者を決定する委 託業務により管理費の縮小が図られている(表 2)。世田谷区は、立 地や利用率から公園ごとに個別の清掃頻度を設定している。しかし 他 2 区は、公園を二種類の規模に分け、立地によらず一律の清掅頻 度を設定し発注している。また三区共通して、外注による効率的管理 のため、「剪定や草刈り」は植物の成長が最大になる時期まで待って 実施し、「清掃」は、污れが最大と考えられる休日明けに実行するよ うに設定されている。このように、世田谷区では各公園の利用状況 に応じた個別の対応がみられたが、三区とも、利用者に快適な状態 で公園を利用させるという姿勢に基づくものではなく、利用者の後 始末をいかに効率的に行うかという点に重点が置かれている。

また公園管理に関する予算の大部分は業者委託費で占められ、こ れと比較して修繥費は極めて低い(図 3)。目黒区は、公園の新設に 応じた予算全体の増額に伴って近年の修繥費は増加しているが、他 二区は、修繒費が予算総額を抑えるための削減対象になっている。 改修等、公園の整備内容を更新するための余地はほとんど残されて いない状況であり、「壊れたら直す」という対応が主といえる。

一方で、近年、住民参加型の管理方法が公園事業の重要な施策と なっている。世田谷区と大田区には、日常清掃を住民ボランティア で行う制度がある。両区とも、月ごとに規模に応じた報奖費が支給 され、管理事務所に管理実行記録を提出することが義務付けられて いる。契約を結んだ団体の内訳は世田谷区では 5 割以上、大田区で は 8 割以上が自治会であり、運営費確保の側面が強い。また制度の 意図として「公園の自由で楽しい使い方を区に提案して欲しいうとい うことが掲げられている。しかし通常利用と同等に公園の利用内容 が制限されていること、管理団体への報奖費が業者委託の単価より 極端に低いこと等から、区の予算削減の一環という側面が強い。さ らに条例や契約内容からも、住民側に委託していることは設備管 理\}や\{環境管理\}に偏っている。すなわち、現状における住民参加型 のしくみは日常清掃という労働を委託するだけにとどまり、利用に 即した管理や空間活用を企画・実現していく\{機能管理\}が不足して いるといえる。

これら行政による管理方法を踏まえ、調查対象公園の利用状況と コミの状態を示す（図 4)。全体的に駅や商店街が近いと、近隣者に 加えサラリーマンや学生等の来訪者が増加し、ゴミの状態が悪化す る傾向にある。一方、住宅街に位置する公園 a, b , d , e, また規模が比 較的大きい i では、比較的良好な睘境が保たれている。公園規模、 清掃頻度、コミの状態の関倸性は捉えられず、世田谷区のように各 公園に対し個別の清掃頻度を設定していても公園 $\mathrm{g}, \mathrm{j}, \mathrm{k}$ は不良な状 態がみられ、利用者マナーにより公園の污れ具合が異なる。特に、

公園 $\mathrm{g}, \mathrm{h}, \mathrm{j}, \mathrm{k}$ では、ゴミの放置が通常利用を制限する哚刻な問題に なっている。このように公園の立地や利用者マナ一により、行政の 現状の管理方法では対応が追いついていない状況がみられ、行政管 理の不十分さと限界性が捉えられた。

以上、行政による管理方法は、信備管理\}、儇境管理\}共に事後処 理型の対応であり、快適な公園利用を保障するための管理方法には なっていないことが問題として挙げられる。特に、公園の立地と現
表 2 各区の公園管理方法

\begin{tabular}{|c|c|c|c|c|}
\hline \multicolumn{5}{|c|}{ 各区の第理内容 } \\
\hline 作業名 & 方法 & 世田谷区 & 犬田区 & 目黑区 \\
\hline 点検 & 直営作業 & 遇 |回 & 週3〜4回 & 题1回 \\
\hline 工事 & $\begin{array}{l}\text { 業者委託 } \\
\text { 直営作藥 }\end{array}$ & \multicolumn{3}{|c|}{ 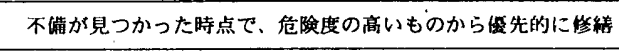 } \\
\hline $\begin{array}{l}\text { 植物の } \\
\text { 手入れ } \\
\end{array}$ & 業者委託 & \multicolumn{3}{|c|}{ 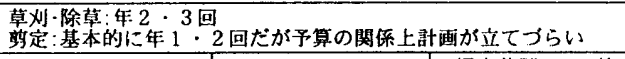 } \\
\hline 清摚 & 業者委託 | & 36〜120回/年 & 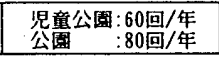 & $\begin{array}{l}\text { 児童公園: 52回/件 } \\
\text { 公園 }: 87 \text { 作 }\end{array}$ \\
\hline その他 & 直営作業 & \multicolumn{3}{|c|}{ 陳情や苦情などは、連絡があった時点で現場に出向(各区) } \\
\hline \multicolumn{2}{|c|}{ 業者委託の単価 } & 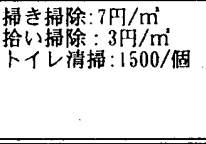 & 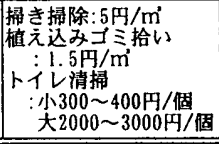 & 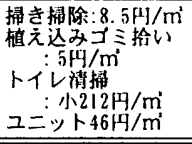 \\
\hline
\end{tabular}

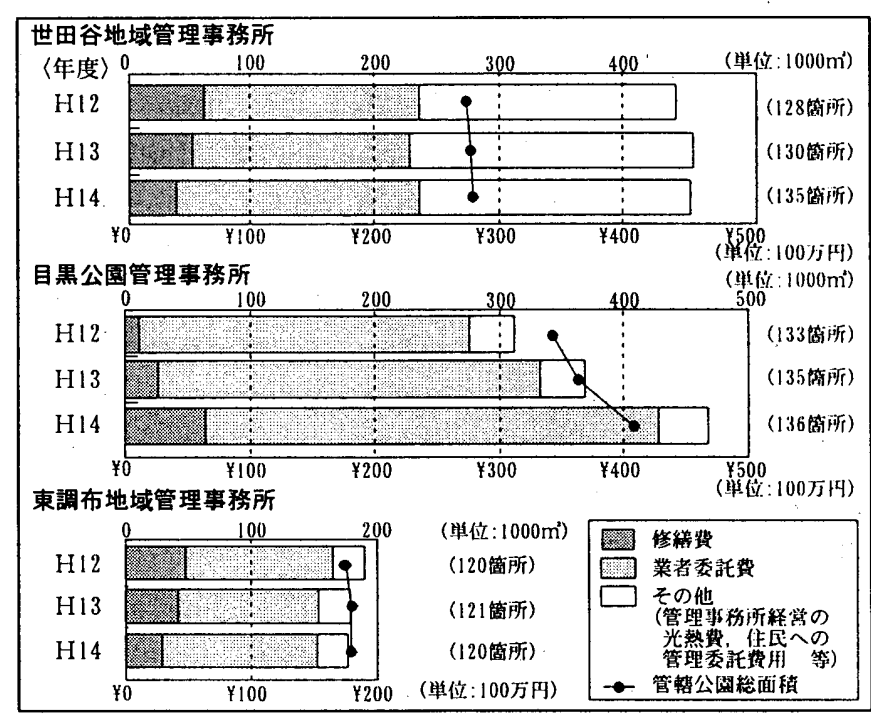

図 3 当該管理事務所の年間維持管理予算亡管轄公園総面積の推移

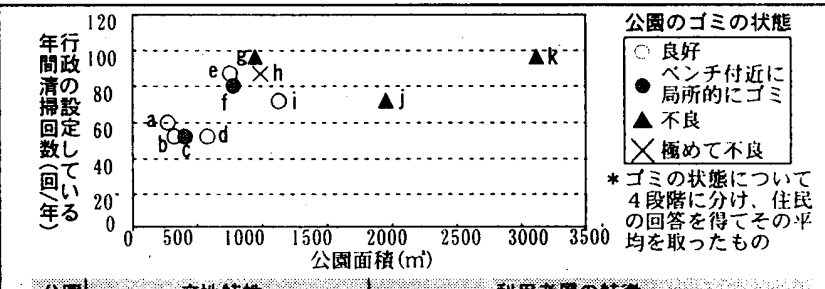

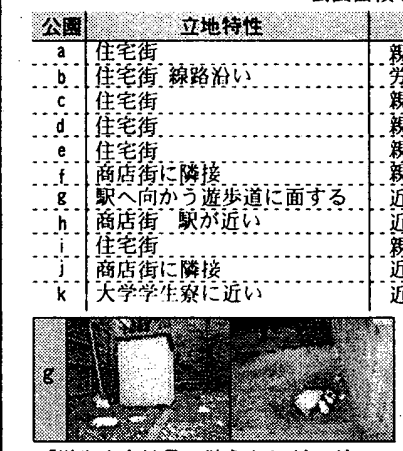

「学生や会社賁の散らかしがひどい」 「するに活されでて供が游んでる。

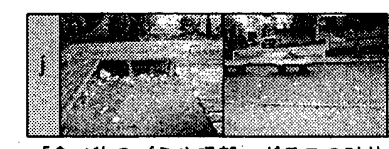

・食へ物のゴミや吸款、ガラスの破片 が斿具の近くにあこて危除」 っていってしまう」

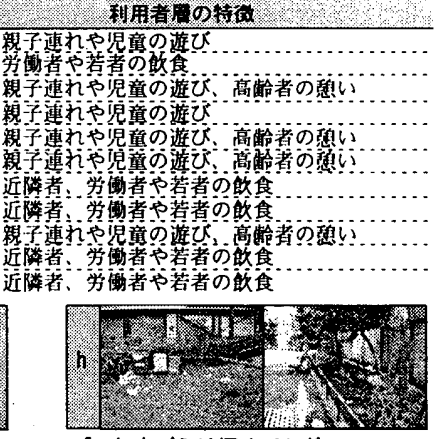

・年中ゴは懦めてひどい。 いつもお酒のビンがある。 ・活くて、詳判の悪い公葍」

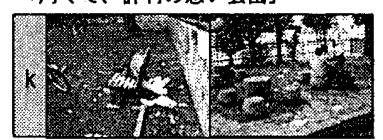

·区がちゃんと㨧除に来てくれている のにそれを上回る速さで;される 污いのでここには来ない人もいる」

\section{图 4 調查対象公園の利用状況とコミの状態}

場の状況に応じた管理方法の再検討が求められる。また、機能管理\} の不足については、住民参加型の取り入れの際に充実させることに より、公園環境に対する住民意識の向上や管理意欲を高め、活用さ れる公園へと整備していくことが重要である。 


\section{3 . 公園内の問題に対する行政、及び住民の対応}

公園内で起きる問題について、「管理者としての行政」と「利用者 かつ管理者にもなりうる住民」がどのような対応をしているかを捉 えることで、公園管理における行政と住民との役割関係を考察する。 3-1 住民からの陳情内容と行政側の対応 世田谷区玉川地域公園事 務所社 6)の過去の陳情件数報告書と行政へのヒアリング結果から、玉 川地域内の全公園に関する問題の内容と量、それに対する行政の対 応方法を捉える。

陳情内容は、公園の環境材料である[樹木の管理]に関するもの、 [設備の不備・故障]に関するもの、[利用者マナー]に関するものの 大きく三つに分けられる。そのうち最多なのは、[樹木の管理]に関 するものであり、近隣者からの剪定要望が主である(図 5)。隣りが 公園という環境的恩恵を受けられる立場にありながら、植生とずれ た時期の剪定要望も多く、行政側が対応に難色を示している状況で ある。[設備の不備·故障]については全体の 3 割程度を占める。これ に対して行政は陳情があった段階で現場へ赴き、修理や使用禁止処 置を行っている。住民からの指摘があって初めて対応するという形 であり、行政の監督業務が不十分な面が指摘されるが、一方では住 民自身の公園管理に対する意識の表れや高さともいえ、住民と行政 間の情報交換や意思蹯通を図りうる機会といえる。[利用者マナ一] についても全体の 3 割を占める。ゴミの問題、夜間利用や騒音、放 置自転車、犬の飼い主の非常識な行為、目的外利用等に関するもの が多く、公共空間での人々のマナーの悪さが表れている。それらに 関連して陳情の中には、園内のベンチやゴミ箱等を撤去してほしい というものもあり、行政は近隣者の声を優先し、禁止事項や空間的 な利用規制を増加させる傾向にある(表 3 )。とくに、従来公園には 必要不可欠なものとして設置されてきたベンチの撤去 (公園 g) や座 り心地の悪い構造への変更、プランタや樹木で広場を縮小する(公園 d) 等、公園での本来の利用を不可能にするような対応がなされてい る。このように、利用規制という方策により、公園の機能が低下さ せられただけでなく、規制の背景にあった根本的な問題は解決され ていないという“負の展開”が捉えられた。

3-2 住民の不満·要望と住民自身の対応 調査対象公園を利用する 住民へのヒアリング調查から、各人が利用している公園に対する不 満·要望を捉え、それら不満・要望に対する住民自身の対応を明らか にする。

公園に対する不満は、駅や商店街が近い公園や比較的規模の大き い公園を中心に、コミの散らかし状態という\{環境管理\}に関するも のが最も多い(表 4 )。これは近隣者・来訪者双方から捉えられた。 また特に近隣者からは、公園の木の葉が家に落ちること、ゴミが飛 んでくること等、自身の生活や居住環境に支障をきたす問題も挙げ られた。しかしながら、行政の管理に対しては「定期的に入ってよ くやってくれている」という好評価が主で非難する声は少なく、そ れよりコミ放置や煙草のポイ捁てを行う利用者マナーに対する非難 の声が多くみられた。

また $($ 機能管理\}に関するものは、 $\mathrm{e} \sim \mathrm{g}$ を中心とした「設備の増設 や新しい設備導入の要望」、d, g を中心に「利用規制により失われた 設備復活の要望」に分けられる。d, g を中心に機能低下が著しく、利 用規制を図る対応だけでは意味がないという行政対応への非難の声 が顕著である。

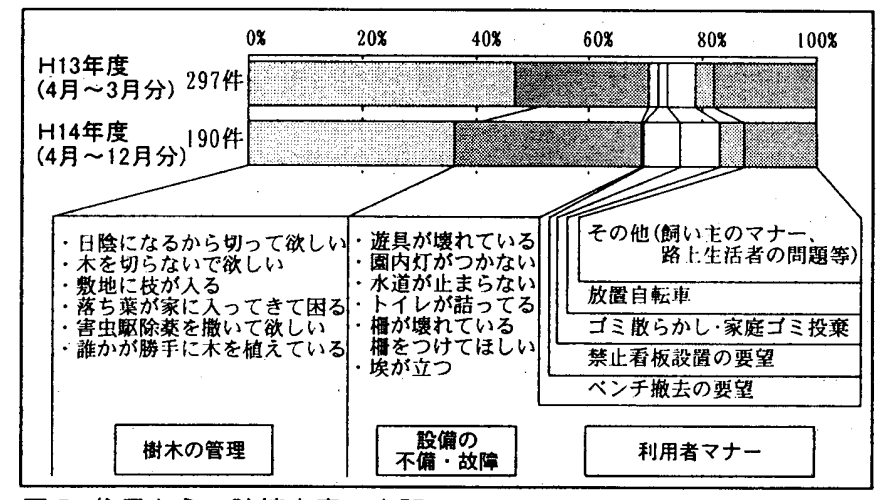

図 5 住民からの陳情内容の内訳

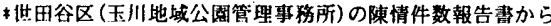

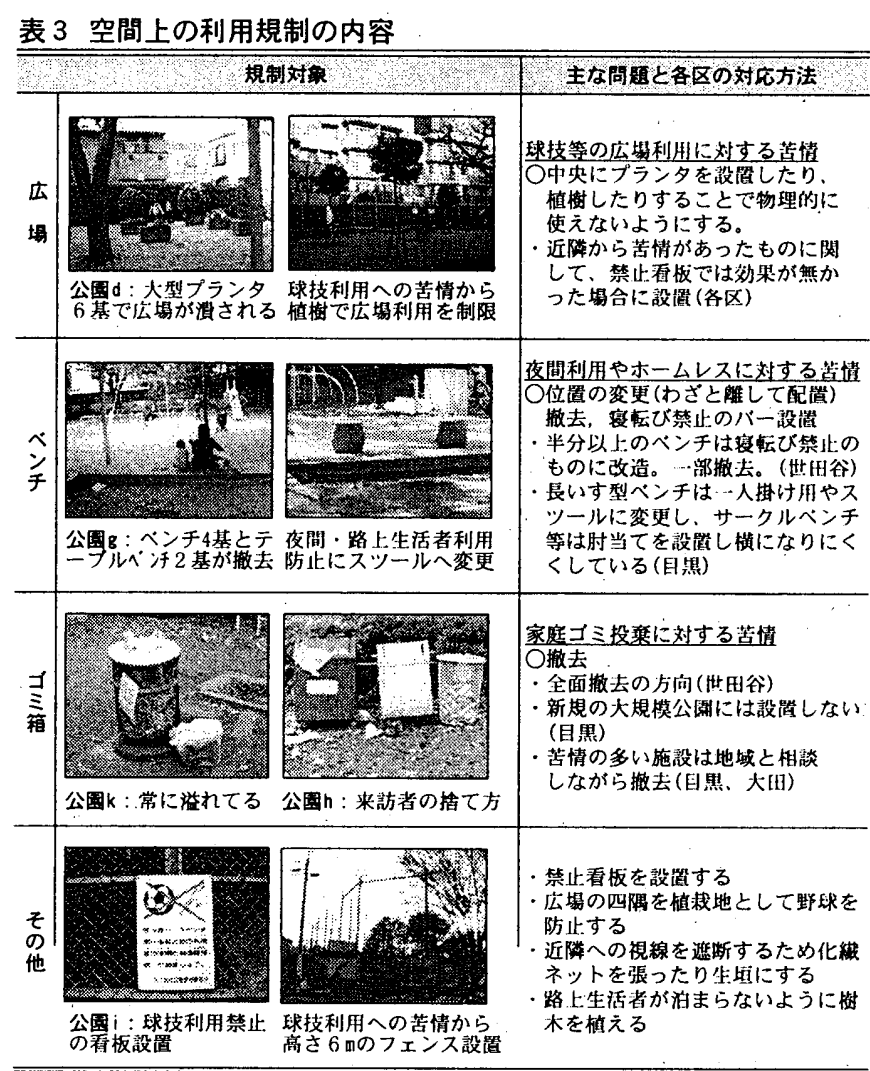

表 4 住民の公園への不満·要望

\begin{tabular}{|c|c|c|c|c|c|}
\hline & 項 目 & 容 & & 愐 & 内 \\
\hline $\mathrm{a}$ & 遊具 & -砂場の䚘生状態 & \multirow[b]{2}{*}{$h$} & \multirow{2}{*}{$\begin{array}{l}\Xi \\
\text { 遊具 }\end{array}$} & \multirow{2}{*}{ 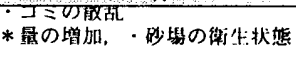 } \\
\hline b & $\exists ミ$ & 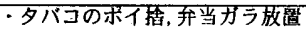 & & & \\
\hline $\bar{c}$ & 遊真 & ·砂場の衛生状態 & & \multirow{2}{*}{ 游具 } & \multirow{2}{*}{ 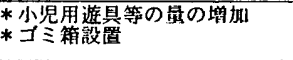 } \\
\hline d & 広場 & *プランタで㵒された広場の使用 & & & \\
\hline e & 避县 & *小児用遊具などの增加 & \multirow{3}{*}{$\mathrm{j}$} & \multirow{3}{*}{$\begin{array}{l}\text { 遊査 } \\
コ ミ\end{array}$} & \multirow{3}{*}{ 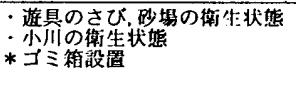 } \\
\hline f & 游真 & *量の增加·すべり台の安企性 & & & \\
\hline & $\exists \equiv$ & ・コミの散乱，*コミ籍設監 & & & \\
\hline g & 遊县 & 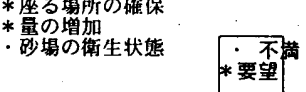 & $k$ & 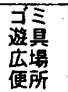 & 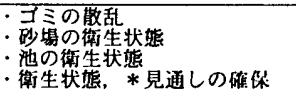 \\
\hline
\end{tabular}

个各公園、ヒアリング対象者の半数以上が挙げた内容を記す。

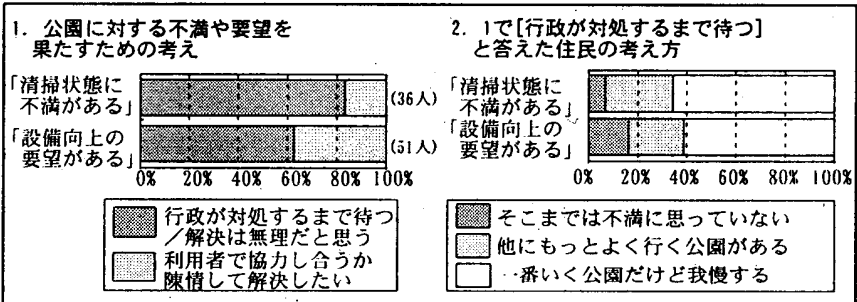

图 6 不満·要望に対する住民自身の対応 
次に不満·要望に対して住民自身の対応を捉える(図 6)。ゴミの状 態への不満や設備向上の要望を持っていても、ともに 6 割以上の住 民は、「不満はあるが、解消するための具体的な行動を起こすより現 状に甘んじる」という消極的な態度を示している。またその内訳と して、6 割以上が「一番利用する公園だが甘んじる」と答え、現状の 水準で我慢したり、遠い公園へ回避する傾向がある。一方で、「利用 者で協力しあうか、陳情して解決したい」という能動的な意見を挙 げた住民は、公園利用を重視している、また距離的なことからこの 公園しか行かないといった特徴がみられた。

来訪者が污したものに対し他の近隣・来訪者が不満をもつ、また 近隣者からの要望で撤去された設備に他の来訪者が不満をもつとい うように、利用者マナーの欠如に基づく“悪循環”を起こしている 公園が捉えられた。これらは現行の行政による現状回復的な管理方 法に加え、住民側の公園環境に対する諦めにより、改善に向かうこ とのない状態に陥つているといえる(図 7)。この悪循環を断ち切り、 また発生させないためにも、問題解決に積極的な姿勢を示した住民 の意見や行動を公園管理に反映させるしくみが重要である。

\section{4 . 住民の整備意向にみる今後の管理方法}

公園の再整備と管理方法に対する住民の意向、また特に近隣者の 公園に対する考えや具体的にとっている管理行為をみることで、公 園管理に対する住民の関わり方を明らかにする。

4-1 再整備に対する住民の意向 規模が大きく広場が確保された公 園に対しては、芝生や水路等、広場を有効に利用したいという、近 場の小規模な公園には望めない整備への意向が強くなる(図 8)。し かし、住民参加を条件にした再整備になると、それらの要望は激減 し現状維持を望む声が圧倒的になる。

その中で管理に参加して再整備をしたいという意向が捉えられた のは公園 $\mathrm{i}$ に限られた。その理由は、 $\mathrm{i}$ では商工会が日常清挦等の 定常的な管理を行っており、そのことを住民側が認識していること にある。つまり公園管理において既に「住民参加型の方法」がある ことで、その他の住民も自主的に参加の態度を示しやすいといえる。

i 以外の各公園についても、それぞれ整備意向に特徴がみられた。 遊具スペース中心に構成され近隣者利用が中心である $a, c$ では、現 状維持を望む声が圧倒的である。設備の老朽化が目立つ c でも、公 園の規模を好む声が多く、単純に公園の見た目を新しくすることは 求めていないといえる。しかし同じ現状維持でも、規模が大きく来 訪者の多い $\mathrm{h}, \mathrm{k}$ では、公園の現状を客観視しこれ以上の整備に対す る諦めから現状維持を望んでいる。

一方、近隣者にとっての公園は少なからず迷惑施設の一面があり、 区に対して苦情や陳情経験がみられる(表 5 )。比較的小規模な公園 (公園 a,b,c,d)では、利用者マナ一に対して不満をもつことが多い半 面、自分たちの庭先という感賞で日常的な目配りを行っている場合 もある。近筷者が行政との管理協定に基づきほぼ毎日公園のゴミ拾 いや花の手入れを行う(公園a)、近隣者が休日に自主的に掃き掃除を 行う (公園 $\mathrm{e}$ ) 等、個々の公園の事情に応じた住民による管理行為がな されていることが確認された(公園 a, c,e,g)。

独立した広場を有する $\mathrm{h}, \mathrm{i}, \mathrm{j}, \mathrm{k}$ になると、公園との間に介在する 道路が多くなり、平面構成にも余裕があり、溜り場を住居部分から 遠ざけて計画できる等の理由から、近隣者の苦情は「落ち葉の季節

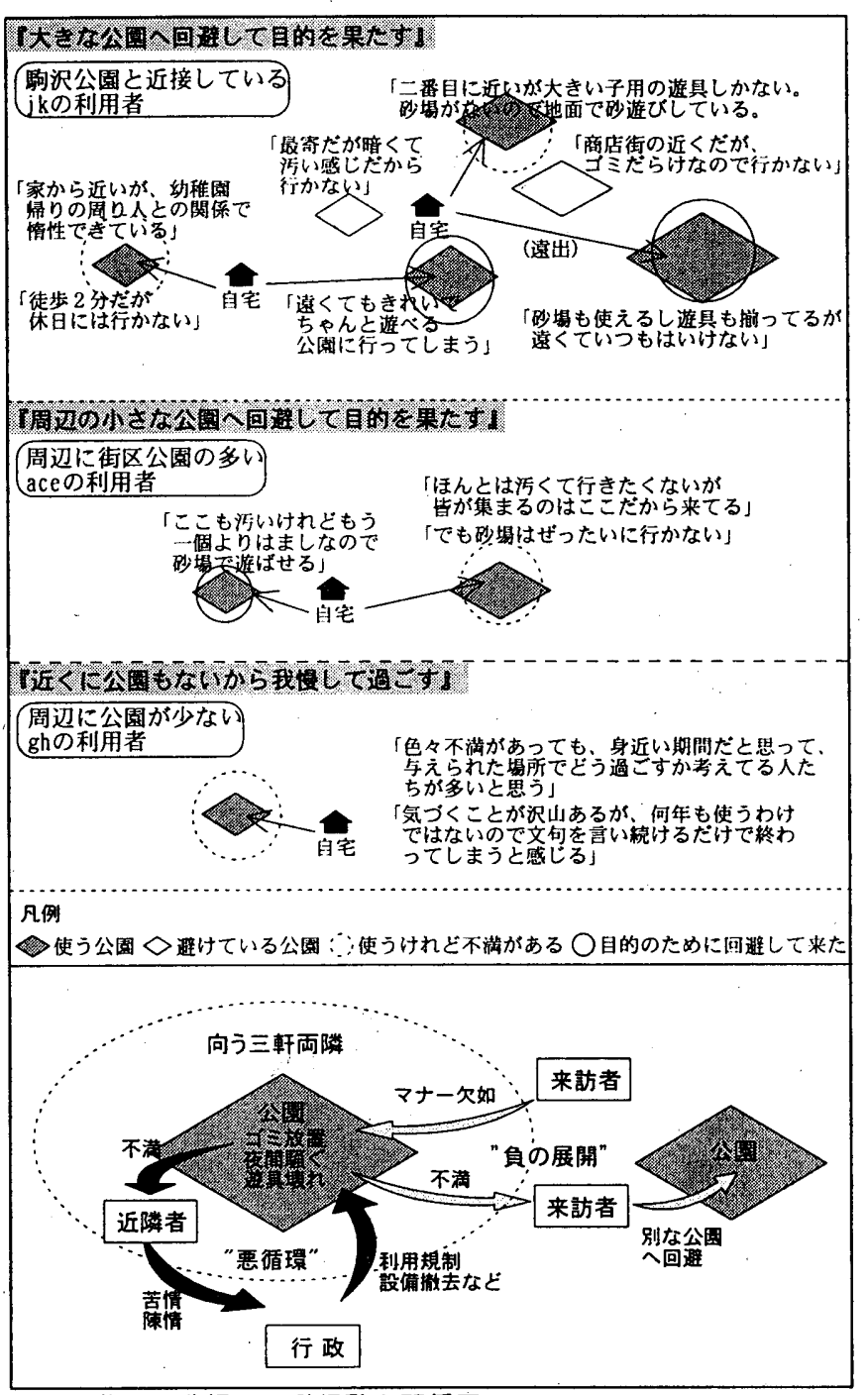

図 7 住民の我慢や回避行動と関係図

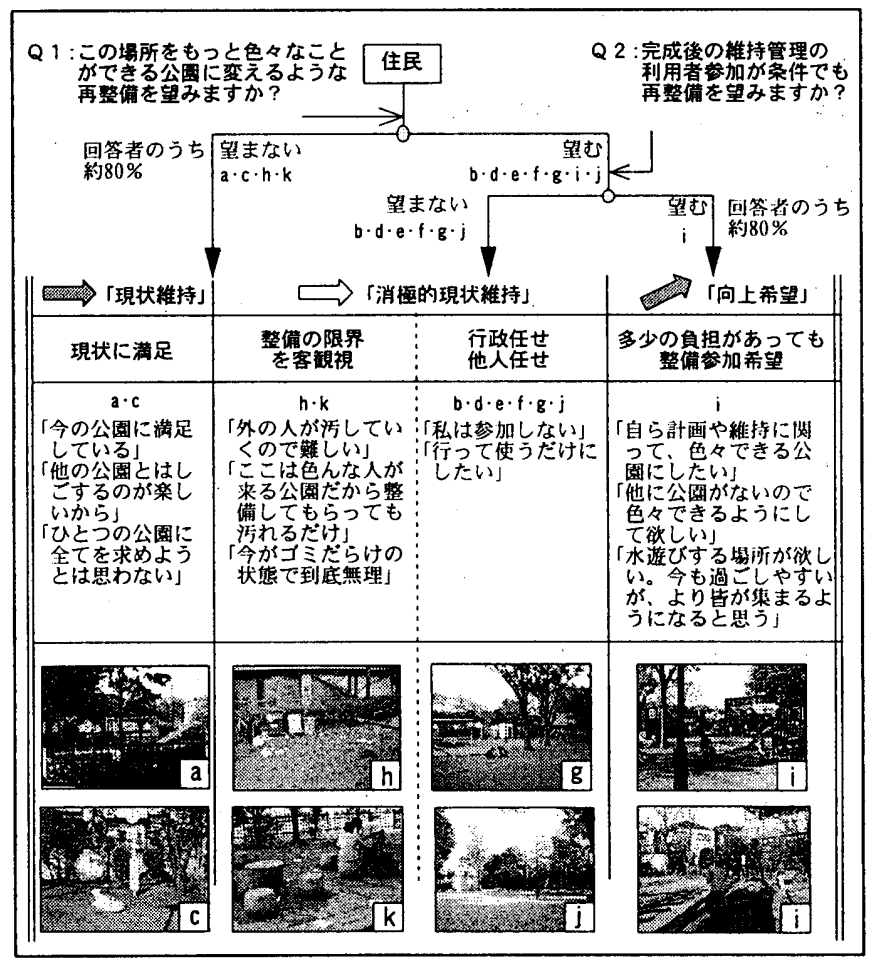

図 8 再整備に対する住民の意向 
に困る」「夏の夜に若者がうるさい」等、季節的なものにとどまる。 住民の整備意向は公園の規模や立地により異なるため、全ての公 園管理におしなべて住民参加をすすめる方法には明らかに限界があ るといえる。ただし、規模が小さい公園においては、近隣者が公園 への身近さから自主的な公園管理を行っている動きも捉えられた。 それら住民による能動的な管理行為を生かし、各公園の特性に即し て、日常の中での持続可能な管理方法を検討することが必要である。 4-2 現行事例にみる今後の管理方法 調査事例の中で住民組織に よる固有の管理がなされていた $\mathrm{a}, \mathrm{i}, \mathrm{j}$ について、それらの組織に対 するヒアリング調查、及び行政に対するヒアリング調査をもとに、 管理方法における住民・行政双方の課題之方針を探る(図 9)。

a では、行政からの管理委託で近隣者が日常清掃を行っている。メ ンバーは公園の隣に住む主婦を中心とした近隣者 3 人であり、自分 たちの庭の延長で気づいた時に管理を行っている。メンバーは規模 の小ささから、無理なく清掃を行い、花植え等により園内環境を良 好に保っている。自宅の庭造りのように楽しみながら、園内の掃き 掃除や花作りを通じて、来訪者との人間関倸が形成されることもあ る。さらには園内の環境を高めるために、行政への提案までも行っ ている。公園の問題に対して一対一の対応がとれ、利用に即した発 展的な管理がなされているといえる。

比較的規模が大きく広場を有する i では、行政からの管理委託で 近隣の商工会が日常清掃を行っている。a と同様、軽運動のように楽 しみながら管理を行っている。また、犬の飼い主のマナー向上に対 する注意喚起等を独自に行うといった取組みもしている。商工会メ ンバー以外の来訪者からも公園の機能向上を求める声が多いことか ら、それらの要望を公園に反映させていくためにも、周辺に対し管 理への参加・協力を促していくことが新たな公園環境の発展につな がるといえる。

比較的規模が大きく広場を有する $\mathrm{j}$ では約 10 年前から、行政から の管理委託で近隣の町会が管理を行っている。年間 15 万円の報奖金 は、町会活動の重要な資金源にもなっている。休日の早朝 10〜20人 が当番制で集まり、掃き掃除や草むしりを実行しているが、これら の活動の捉え方は町会メンバーにより異なる。日常清掃をプラスに みるメンバーがいる一方で、「町会長の独断で掃除をしなければいけ ないのはおかしい」とマイナスにとらえるメンバーもいる。つまり、 現時点では町会活動における義務的な一行事という意味合いが強い。 他方、注目されるのは、町会長が来訪者・近隣者と行政間のパイプ 役になっていることである。公園で起こる遊具の不備や利用者マナ 一の問題を、公園近くに住む町会メンバーが把握する。それを町会 長に街角で出会った時などに連絡し、最終的に町会長が管理事務所 に通告するという連絡ルートが形成されている。近隣関係の哚さゆ えの住民による組織的な管理方法といえる。

以上、近隣者による管理は、単に日常清掃を実行するだけでなく、 公園の問題への対応がなされやすく、かつ改善や機能向上が図られ ている。ただしこれは、日常的に公園に目配り可能な向こう三軒両 隣ほどの近距離に住んでいる近隣者が管理を担っていること、近隣 の住民組織により機能向上の取り組みがなされていること、町会長 等の地域リーダーの関わりがあることという条件がそれぞれに影響 していると考えられる。

\begin{tabular}{|c|c|c|c|}
\hline & (1) 1 BCU & 青 摬 & 区への陳传 ・提案 \\
\hline \multirow[b]{2}{*}{$d$} & \multirow{2}{*}{ 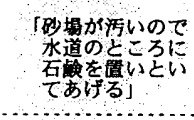 } & \multirow{2}{*}{ 「息分の庭の延長 } & \multirow{2}{*}{ 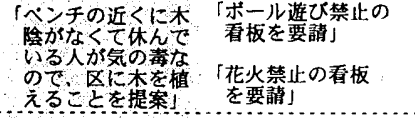 } \\
\hline & & & \\
\hline & & & $\begin{array}{l}\text { 「檄木の新定を要請」 } \\
\text { 「遊具の故障を連絡」 }\end{array}$ \\
\hline 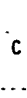 & $\begin{array}{l}\text { 砂堨のネ忘れをみて } \\
\text { いる }\end{array}$ & 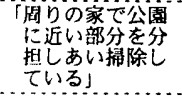 & $\begin{array}{l}\text { 「子供が家まで入っ } \\
\text { て来て花椬を增す」 }\end{array}$ \\
\hline & $\begin{array}{l}\text { 子供が谙いてい } \\
\text { ると行く」 }\end{array}$ & & 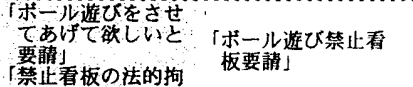 \\
\hline & 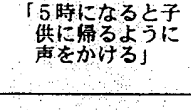 & . & 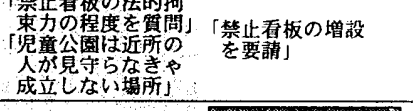 \\
\hline & ボール旅びの子 & 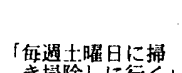 & 案, \\
\hline & 尔ヤ板を設置」 & & 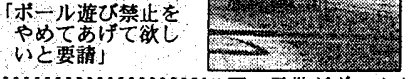 \\
\hline 3 & 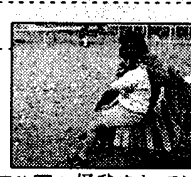 & 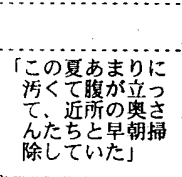 & $\begin{array}{ll}3 \\
0\end{array}$ \\
\hline & \multirow{2}{*}{ 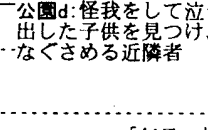 } & & 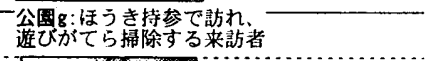 \\
\hline & & $\begin{array}{l}\text { 「商工会で掃除 } \\
\text { をしいる」 }\end{array}$ & 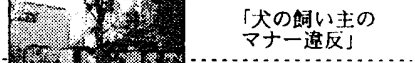 \\
\hline & $\begin{array}{l}\text { 「每日、 } \\
\text { 个町会て }\end{array}$ & 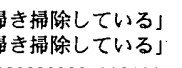 & W \\
\hline r & $\begin{array}{l}\text { ひっく } \\
\text { を直し }\end{array}$ & 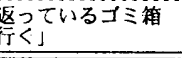 & 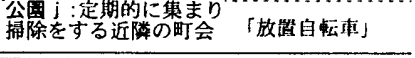 \\
\hline
\end{tabular}
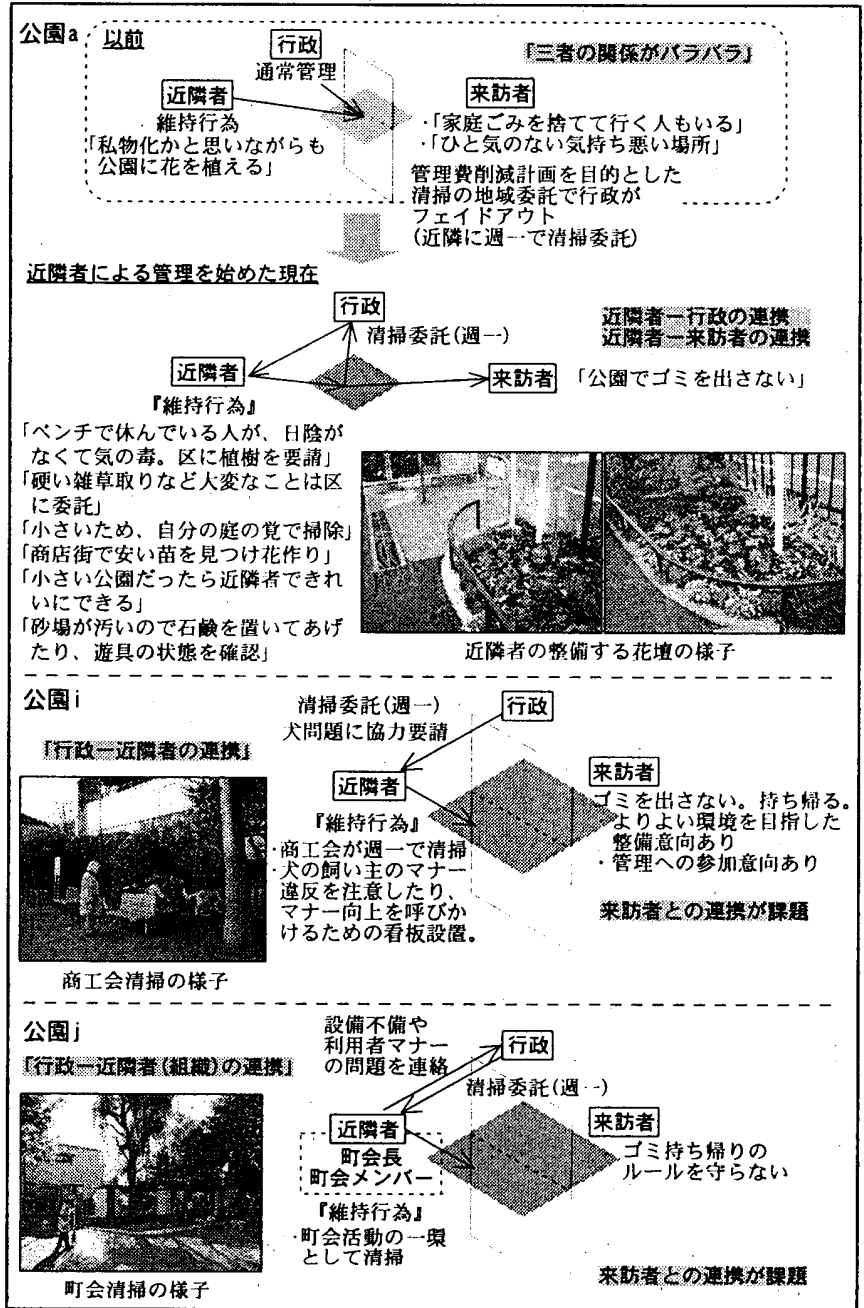

図 9 公園a, i, jの管理方法 


\section{5 .まとめ}

都市居住地において、暮らしに身近、かつ重要な空間である街区 公園、及び児童遊園について、行政、近隣者、来訪者、それぞれの 立場での公園管理への関わり方を捉え、問題点の抽出と空間活用に 向けた管理方法の計画課題を明らかにした。結果を以下にまとめる。

1）行政による公園管理の実態は、最低限の現状維持と事後処理 型の対応·修繥に加え、住民からの苦情に対し公園利用の制限・禁止 措置を図ることにより、公園自体の機能低下が著しいという問題が 捉えられた。快適な公園利用を実現していくためにも、清潔な状態 を保ち、かつ公園の機能を向上させるという視点を盛り込んだ管理 方法へ転換することが重要である。その際、特に立地と現場の状況 に応じたきめ細かい個別対応の検討が求められる。

2）また、利用者マナーの欠如に対して、行政による公園管理の 限界性が捉えられた。住民自身のマナ一向上と互いのチェック機構 を高めていくためにも、公園における問題を住民側が能動的に解決 していく意識の形成が重要であり、その一つの方法として管理にお ける住民参加は有効である。

3）一般的に、住民は現状の公園利用に不満・要望を抱いていて も、機能向上のための行動に対する参加意向は低い。ただし、一部 の公園では近隣者による自主的な管理行為が確認され、公園の個々 の問題を柔軟に解決し、機能向上させていることが得られた。また、 来訪者の中から住民組織の管理活動への参加や環境改善に取り組み たいという意向も捉えられた。これら近隣者の公園管理に対する行 動や来訪者の整備意向を、行政は着実に捉え施策に取り込んでいく ことが、個々の公園事情に即した住民参加型管理の形成につながる と考えられる。

4）行政側が設ける現行の住民参加型の管理のしくみは、日常清 掃の委託にとどまっている。また、公園ごとに利用状況や要望が異 なるため、全ての公園におしなべて画一的な住民参加型をすすめる ことには限界があると考えられる。管理方法として、小規模な公園 は近隣者、中規模以上の公園は住民組織を公園管理のコアメンバー とする等、単なる労㗢提供に終始せず環境改善の企画・実施を図る \{機能管理\}を充実させ、住民の日常行為の中で持続的に行われる管理 方法に改変することが求められる。

5） 今後の管理方法において、各公園に共通する要件としては、 良好な環境を維持していくという行政による計画的な\{設備管理\}、 \{環境管理\}、及び住民参加型管理における\{機能管理\}の充足化が必要 である。また、地域性による個別の要件としては、公園の立地や規 模に応じて近隣者や住民組織をコアとした、行政・住民協働による 管理方法を作り上げていくことが求められた。
[注䣋]

注 1）都市公園法において「主として街区内に居住する者の利用に供するこ とを目的とする公園で誘致距離 $250 \mathrm{~m}$ の範围内で一ケ所当たり面積 $0.25 \mathrm{ha}$ を標準として配置する」と定められた誘致圈・䙺模ともに最小の都市公園。 平成 5 年の法改正により、旧法下で遊戯施設の設圆基隻が限定されていた 「児童公園」は、公園名称はそのままで種別のみ街区公園として极われる こととなった。

注 2）览童福祉法において「児童厚生施設は、忨童遊園、児童館等児童に健 全な遊びを与えて、その健康を增進し、又は情繰をゆたかにすることを目 的とする施設とする。」と定められ、施設の最低基準として「児童遊 園等屋外の児童厚生施設には、広場、遊具及び便所を設けること。」とし ている。特に都市部では用地取得の難しさから、街区公園よりも小規模、 かつ整備内容は類似したものを数多く整備できるという点が挙げられる。

注 3）「戦災復興特別都市計画」、1954 年制定「十地区画整理法(公園三\%保留 条項)」、1972 年制定開始「都市公園等整備厉力年計画」等により、公園数 の增大をはかる全国的な流れ。

注 4）街区公園と児童遊園は、(1)面積・誘致距離の面において双方とも住民 の薮らしに身近な施設であること、(2)自治体の管理面における报いに差が ないことから、两対象を取り上げた。

洼 5）都市公園法の公園施設の定義（第１章第２条2）では、「施設」としてべ ンチや遊具等の道具的な要素と、園路や広羕、植耕といった空間的なまと まりをもつ要素を同列に扱うため、維持管理内容との対応の際に不都合が 生じる。そのため本研究では、公園施設を「路路および広場」「ベンチ. 遊具などの設備 (二〜四における植物以外の造固材料で粠成される施設) 」 「植栽・樹木」と個别に捉えて分析を進める。

注 6）陳情内容は、各自治体共にヒアリングを行い内容を把握したが、孹・ 量共に客観的な分析ができる資料を備えた世田谷区のみを考察の対象と した。また、陳情内容とそれへの対応方法はおよそどの区においても同 棫・類似している。

\section{[参考文献]}

1）神田徳蔵：幼罗・低作踰児童の利用公園数及び利用先公園志向性に関する 考察, 暃外遊び場施設の地域的整備に関する公園利用形態の研究, 日本建 築学会計画系論文集, 10.493, pp. 125, 1997.3

2）神田徳蔵：児童公園等戸外遊び場の利用時間に関する考察，日本建築学会 計画系論文集, $10.499, \mathrm{pp} .49,1997.9$

3）神田徳蔵：児童公園等开外遊び場の利用者誘致特性に関する考察, 户外遊 び場施設の地域的整備に関する公園利用形態の研究その 2 , 日本建築学会 計画系論文集，N0.505, pp. 97, 1998.3

4）山口紘，坂本啟雄，田中正美, 前田修: 街区公園に関する研究 その 1 . 能 本市における児童公園の実態と住民の対応について, 日本建築学会大会贸 概集, F-1, pp. 665, 1996

5）今村洋 - - 広場公園の施設構成・利用実態について（関東地方の広場公園 を事例として）,日本建策学会大会梗概集，F-1,pp.33,1997

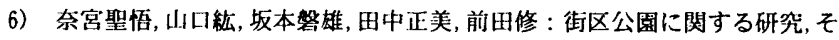
の 2. 熊本市における街区公園の校区別筒所数・面積・配監の現状につい て, F-1, pp. 735, 1997

7）木多彩子，安田孝: 街区公園の周过㻴境と利用奏態に関する研究，大阪市爬 区を事例として,E-2, pp. 669. 2002

8）シーポシュ・ラースロー，後滕春彦，占田道郎，阔村竹史：熊本県小国町此 里地区における公園づくりクークションプ，その、公图づくりの背景と活動の流 れ, E-2,pp. 471, 1997

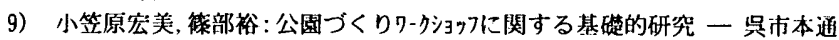
第 2 公園を事例として一,F-1, pp. 277, 2000

10）加藤浩同，北原理雄：都书近郊における市民主体の自然琵境管理システム 実現過程，一千葉目柏市・酒井根下田の森自然公園の場合一, 日本建築学: 会計画系論文集, N0. 542, pp. 161, 2001.4

11）梁田鿆子，水口俊典：オープ 冺・゙ーブくりにおける住民参加とその継続性〜 羽根木プレーペークと权こじゃらし公園の事例を通して〜,F-1, pp. 275, 2000 